\title{
Social Relations, Regional Variation, and Economic Inequality in Contemporary Vietnam: A View from Two Vietnamese Rural Communities
}

\author{
Hy V. Luong
}

The salience of social connections or social capital in Vietnam is summed up in a contemporary Vietnamese saying regarding different factors of importance in the Vietnamese labour market: 'nhất hậu duệ, nhi quan hệ, ba tiền tệ, bốn trí tuẹ' ('Of first importance is descent; second are social relations; third is money; and fourth is the intellect'). Such a saying may over-simplify reality, but it is a fact that ethnic Vietnamese from all walks of life think first and foremost of social connections in their search for the solutions to various problems in their daily lives: from the purchase of a motorcycle and many other consumer durables, to medical treatment for a family member, to securing a job, a loan, or a business contract.

In both the quotidian maintenance and cultivation of social relations, and in their mobilisation in moments of need, ethnic Vietnamese usually invoke 'sentiment' (tinh cảm). Notwithstanding the strong local ideological emphasis on 'sentiment', the maintenance and cultivation of social connections or social capital require the investment of time and material resources; time and material resources needed in offering advice, giving gifts, doing favours, or in hosting death-anniversary 
meals and wedding banquets, among others. In this context, people from different social strata are far from being on a level playing field. This is reflected in my research data over the past decade from two Vietnamese communities, the village of Hoài Thi (2012 pop. 1,141) in the northern Red River Delta, and the community of Khánh Hậu (2012 pop. 14,213) in the southern Mekong Delta, which have both experienced good growth in income in this period. ${ }^{1}$ However, my field data show not only some impact of wealth and socioeconomic stratification on the cultivation of social capital, but also of a major regional variation in social capital configuration. Northern villagers' social connections include many relations formalised through the establishment of patrilineages and numerous voluntary associations, in contrast to the pattern in rural southern Vietnam. Northern villagers also mobilise their social connections more effectively, at least in terms of material assistance from people in their networks. Towards the end of the chapter, in reference to the larger debate on the salience of social connections in the political economy and sociocultural fabric in some other East Asian societies (for example, Gold et al. 2002:10-17; Walder 1986; Yang 1994, 2002), I argue that it is problematic to attribute the salience of social connections in Vietnam solely to the shortage of goods and services, the weakness in the Vietnamese formal institutional framework (lack of strong commitment to institutional rules),

1 Khánh Hậu is well known in the literature on Vietnam as it was studied in the late 1950s by three American social scientists and their Vietnamese research collaborators (Hickey 1964; Henry 1964). In 2006, although most of its land was still used for agriculture, Khánh Hậu was incorporated into the municipality and provincial capital of Tân An due to its proximity to Tân An, and divided into two 'urban' wards (phường), Khánh Hậu and Tân Khánh. In this chapter, I use 'Khánh Hậu' to refer to both of the recently created wards and their population $(7,863$ in Khánh Hậu and 6,350 in Tân Khánh in 2012). Khánh Hậu is located at about 55 kilometres from Hồ Chí Minh City, while Hoài Thị is situated about 30 kilometres from Hà Nội. In 2012, Khánh Hậu's population was 12.5 times larger than Hoài Thị. Khánh Hậu's area was also 21.8 times larger than that of Hoài Thị (1,073 hectares in contrast to 49.3 hectares). Hoài Thị villagers have a very strong sense of identity and live in a nucleated settlement, quite distinct from the five other villages (thôn) in the commune of Liên Bão. This strong village identity, below the commune level, is typical of the Red River Delta of Northern Vietnam. In contrast, Khánh Hậu is a spatially dispersed community, with no clear boundaries among its hamlets (ấp) and no strong identity among the population of any hamlet.

I first conducted research in Hoài Thị and Khánh Hậu in 1990-92. I have carried out systematic and comparative research on these communities three more times in the past decade and a half, with primary funding from the Social Sciences and Humanities Research Council (SSHRC) of Canada, and with the collaboration and assistance of Vietnamese researchers at the University of Social Sciences and Humanities in Hồ Chí Minh City, the Southern Institute of Social Sciences, the Ethnology Institute, and the National Institute of Cultural and Arts Studies. 
the subsequent uncertainty in the social environment, and people's mobilisation of social capital for problem solving. This salience is also partly and deeply rooted in local models for and of social reality.

\section{Social Connections in Local Sociocultural Fabric: A View from Two Rural Vietnamese Communities}

To the extent that ethnic Vietnamese consider social connections or social capital a fundamental aspect of their lives, these connections are not only mobilised in daily life. These relations are also ritualised in the attendance and gifts at life cycle events such as weddings and funerals, and, to a lesser extent, in the invitation to and attendance at the annual death anniversaries of relatives and acquaintances. As average income has significantly risen in the past three decades in Vietnam, the financial investment in the cultivation of social connections has increased correspondingly. This increased investment is partly reflected in the size of weddings, funerals (Figures 1 and 2), death anniversary feasts, and, in northern Vietnam, in the revitalisation and creation of patrilineages and numerous voluntary associations to strengthen social capital.

In Hoài Thị and Khánh Hậu, the average number of visitors at funerals in studied households increased respectively by 66 per cent and 88 per cent over three-and-a-half decades (respectively from the average of 160 in 1976-85 to 265 in 2006-12 in Hoài Thi, and from 146 to 274 in Khánh Hậu). ${ }^{2}$ As a widely shared Vietnamese practice, one pays respect to the deceased not only when the deceased is one's relative, friend, co-worker, or a member of the nuclear family of one's

2 As Hoài Thị had a small population, a census was conducted in the entire village in 2000, 2005, and 2012, focusing on household economy and social capital. A survey using the same instrument was carried out in Khánh Hậu in 2000 using a random probability sample of 340 households. This sample increased to 367 households in 2005 and 411 in 2012 in order to include households splitting off from the original sample and to reflect the increase in population. In 2005, in the research project on gifts and social capital, the Dinh hamlet in Khánh Hậu was also chosen for in-depth research on gifts and social relations, in comparison with Hoài Thị. The method of participant observation was also used in 81 of the surveyed households (40 in the Dinh hamlet of Khánh Hậu; 41 in Hoài Thị) for two months in 2005 and for a shorter period in 2012. Most of these households also recorded their gift flows from February 2005 to January 2006. In-depth interviews were also conducted with 111 of the surveyed households (40 in the Dinh hamlet; 30 in other hamlets of Khánh Hậu; 41 in Hoài Thị) in 2005 and 2012. 
friend/co-worker, but also when the deceased is a parent or parentin-law of one's friend and co-worker (tứ thân phụ mẫu), even when the deceased did not reside in the same household with the latter. These funeral visits are made without invitation from the family or relatives of the deceased. Visitors routinely present cash gifts to help defray funeral expenses, unless, as an option among the well-off in southern Vietnam, the family of the deceased publicly announces the non-acceptance of cash gifts. (When the family of the deceased in Khánh Hậu or in southern Vietnam does not accept cash gifts, visitors usually bring incense and fruits.) In native discourse, the visit and the gift reflect the sentiment (tinh cam) of the visitor towards the deceased and/or his/her family members. They also help to reaffirm a visitor's social bond with the spouse, or parents, or descendants of the deceased.

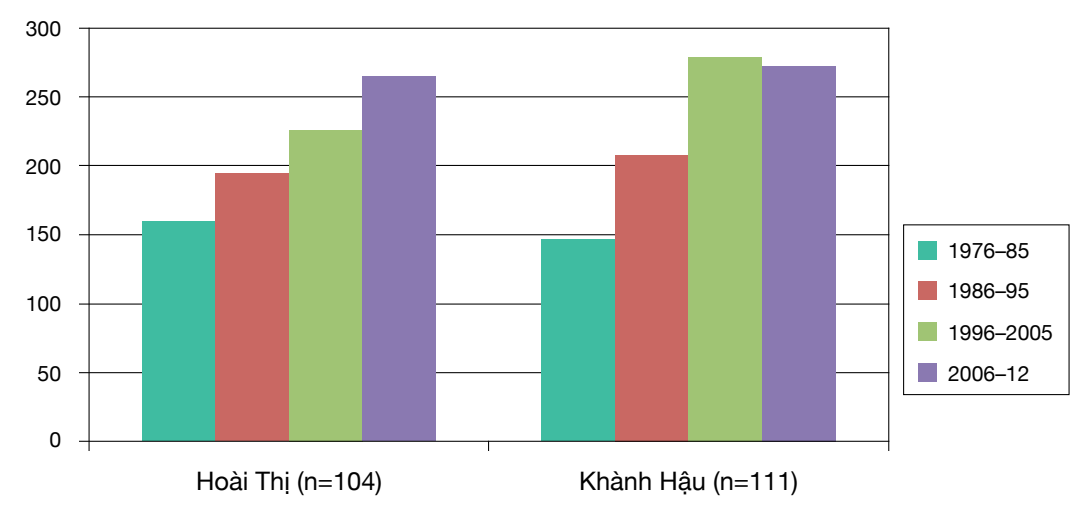

Figure 1: Average number of visitors to funerals in surveyed households since 1976.

Source: Author's research.

At weddings, the invitation list is determined not only by the bride and the groom, but also by their respective family members. (In both of the studied rural communities, the bride and groom's families normally hold separate banquets and have independent invitation lists.) Besides relatives, friends, and co-workers of the bride/groom, and friends and co-workers of the parents of the bride/groom, very close friends of the bride/groom's adult siblings are also usually invited. Invitations reaffirm not only the social relations of the bride and groom, but also those of their parents and adult siblings. This extension of invitation to people in the social circles of the bride/groom's parents and adult 
siblings is facilitated by the widespread use of kin terms among speakers of Vietnamese to address the (close) friends of one's parents and siblings.

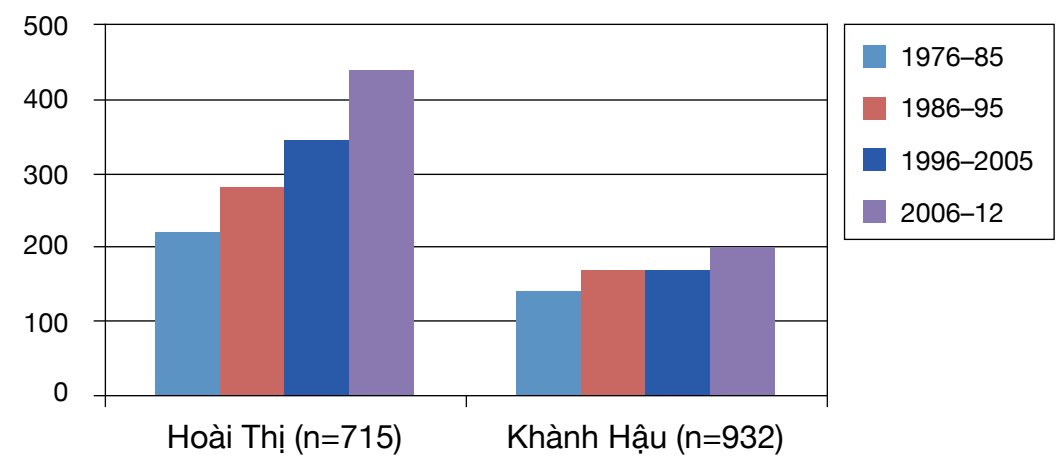

Figure 2: Average number of wedding guests in Hoài Thị and Khánh Hậu, 1976-2012.

Source: Author's research.

Nowadays, wedding guests routinely make cash gifts which normally cover or exceed estimated meal costs. However, special relations with the bride/groom and with his/her parents and siblings are symbolised by much larger gifts, if guests' economic conditions allow them. More specifically, the bride/groom's grandparents, aunts and uncles, first cousins, and close friends normally make much larger gifts than other guests, and may choose to make gifts in gold (necklaces, bracelets, earrings, etc.) instead of cash. The size of the gift also depends on the giver's economic circumstances, as one informant in Khánh Hậu explained to me regarding the cash gifts by his siblings to his daughter at her wedding in 2004:

HL: I would like to ask more about [the gifts from] the maternal aunts and uncles of the bride [interviewee's daughter] ... I see here that Mr Năm gave 200,000 VND; that Mrs Bảy in Thủ Tửu [hamlet] gave 500,000 VND; that Mrs Tư ... gave only 50,000 VND; that Mr Tám gave 100,000 VND. Those four people are full brothers and sisters. Why were their gifts so different?

Male Interviewee: Let me tell you ... Mrs Bảy gave 500,000 because she was wealthy. Mr Năm gave 200,000 because although he was fairly well-off, he was less wealthy than Mrs Bảy. Mr Tám gave 100,000 VND because he had to take care of ancestral worship in his 
house, and because he was not that well-off. Mrs Tư was poor. She was married, but lived without a husband. She [consequently] gave 50,000 VND. When her children get married, I will give gifts of 50,000 VND ... And when a child of Mrs Bảy who gave 500,000 VND gets married, I will give back 500,000 VND ... It [the gift] depended on the giver's circumstances. Whatever he/she gave, I will give back the same amount. (Hy V. Luong's interview with the male head of Household 9 in Khánh Hậu)

However, the principle of strict reciprocity in the above excerpt is more applicable among non-relatives and distant relatives than in close friendship and kinship relations. In the context of close relations, the size of the gift also depends on the circumstance of the recipient. When I asked the male head of Household 48 in Khánh Hậu why he had given a wedding gift of 300,000 VND (\$18.91 USD) to his nephew (deceased elder brother's son) and only 100,000 VND (\$6.30 USD) to his wife's nephew (wife's elder brother's son) in the early 2000s, he emphasised his sympathy for his nephew growing up without a father in contrast to the much wealthier household of his wife's brother.

Vietnamese families in Hoài Thị, Khánh Hậu, and, in fact, throughout the country, carefully keep the lists of gifts at weddings and funerals for one to three decades for the purpose of reciprocity. The act of reciprocity does not have to be performed on the same occasion (a wedding gift for a wedding gift, a funeral gift for a funeral gift); it can be for a variety of events or occasions. It also does not have to be in the same form of gift (cash gift for cash gift); a generous cash gift can be partially reciprocated by such favours as more attentive or expedited services (sales, medical, bureaucratic, etc.) or service fee reduction (discounted prices, waived fees, etc.). Favours can also be reciprocated by generous cash gifts at weddings, funerals, and other ritual events. More generally, gifts not only reflect social relations but also actively structure social relations, giving advantage to those people who can afford generous gifts.

Annual death anniversary feasts are less elaborate and smaller in scope than weddings and funerals. To the extent that the death anniversary organiser's economic resources allow a more extensive invitation list, death anniversary feasts are not restricted to the spouse, children, parents, siblings, and other close relatives of the deceased. Also invited are close friends of the deceased and their spouses, fairly close friends of the event organiser and of the organiser's children, parents and possibly 
some siblings of the organiser's children-in-law, among others. Some death anniversary feasts in Hoài Thị and Khánh Hậu have 150-250 people in attendance, especially the first major one after the funeral. In Hoài Thị, as local authorities have taken a stand against feasting visitors at funerals, as a symbol of gratitude families of the deceased invite funeral gift givers to the first major death anniversary on the 49th or 50th day after the passing of the deceased. The invitation lists to first death anniversaries in Hoài Thị usually comprise more than 100 names. Beyond first death anniversaries, it is not uncommon for Khánh Hậu and Hoài Thị households of some means to host 60-150 guests at their most important annual death anniversaries. In Hoài Thị, death anniversary guests nowadays usually bring incense and cash gifts, a controversial departure from the once prevalent practice of not giving gifts to fellow villagers at death anniversaries (see Luong 2010:408-409). ${ }^{3}$

The controversial and quickly spreading practice of cash gifts at death anniversaries in Hoài Thị was reportedly started by young villagers, many of whom had not reached a life stage of being responsible for organising death anniversaries of ancestors. Unable to reciprocate the death anniversary feast invitations by their relatives and acquaintances, they felt the need to make cash gifts at death anniversaries. An elderly Hoài Thị village leader commented on this new practice:

The cash gift practice at death anniversaries started with young people just three to four years ago [around 2010-11] ... For a long time, we had instituted the rule of no gift whatsoever when villagers attended death anniversaries within the village ... People followed this practice for a while ... Then, as living conditions improved, people began bringing fruit to death anniversaries. One year, at the death anniversary of the mother of a retired official whose children all lived far away, there was so much fruit that this retired official's wife decided to re-sell it afterwards, as the fruit could not be given to her children and grandchildren, this was not well received in the community ... We consequently instituted the rule of no fruit gifts and re-affirmed the rule of no gifts at all at death anniversaries. It was observed for a few years. Then younger villagers began giving cash gifts, as they felt awkward coming empty-handed to a death-anniversary feast. As some people made cash gifts, those without gifts felt awkward and made cash gifts too ... Nowadays, a family may spend a few million đồng a

3 In my ongoing re-study of seven rural communities in three regions of Vietnam, Hoài Thị is the only one where gifts at death anniversaries can take the form of cash. 
year on gifts on those ritual occasions, because for a funeral, the gift is 100,000 đồng at a minimum, to be followed by a 100,000-đồng gift at the 50th-day death anniversary.

The practice of cash gifts at death anniversaries started with younger Hoài Thị villagers because few of them had entered the life stage when they could host death anniversaries for deceased parents. Among middle-aged and older villagers in both Hoài Thị and Khánh Hậu, it is a common practice for brothers to divide the hosting of feasts on the death anniversaries of parents among themselves so that they can reciprocate relatives and friends who have invited them to death anniversary feasts and other events (see Luong 2013).

\section{Regional Variation in Social Relational Configuration}

Many similarities between Hoài Thị and Khánh Hậu notwithstanding, wedding banquet data (Figure 2) show an important difference in the social relational configuration between the two communities. More specifically, Hoài Thị villagers have invested considerably more time and resources to cultivate social connections, informal or formal, than people in Khánh Hậu.

The self-recordings from February 2005 to January 2006 by 64 households (23 in Khánh Hậu and 41 in Hoài Thị) regarding the ritual events where gifts were (potentially) exchanged and social connections strengthened, reveal that Hoài Thị households on average attended many more such events in a year than their Khánh Hậu counterparts (55.8 events on average in Hoài Thị, compared with 32.8 in Khánh Hậu). ${ }^{4}$ The average number of death anniversaries and weddings attended by Hoài Thị households was twice as many as that attended by those in Khánh Hậu; and 11 times as many house construction celebrations (see Table 1). These household self-recordings are congruent with the data on household-organised and invitation-based events such as weddings, showing that the size of these events has

4 In Khánh Hậu, only 29 of the 35 households agreeing to self-recording for one year recorded the events with gift exchanges attended by the members of their households. In my interviews with 35 Khánh Hậu households in November and December 2006, I determined that the selfrecordings by six of 29 households were far from complete, and that we had reliable data from only 23 of the 35 self-recording households. 
increased much more significantly in Hoài Thị than in Khánh Hậu over the past three-and-a-half decades. They confirm that Hoài Thị villagers made stronger efforts to cultivate social ties.

Table 1: Average number of gift-exchange events attended over a 12-month period by studied households in Hoài Thi and Khánh Hậu, 2005-06.

\begin{tabular}{|l|r|r|}
\hline & Hoài Thị & Khánh Hậu (Dinh hamlet) \\
\hline Number of events attended & 55.8 & 32.8 \\
\hline Of which: & \multicolumn{2}{|c|}{} \\
\hline Death anniversary & 27.8 & 13 \\
\hline Wedding & 21 & 11.4 \\
\hline Funeral & 2.8 & 4.5 \\
\hline House construction & 2.2 & 0.2 \\
\hline Other & 2 & 3.7 \\
\hline
\end{tabular}

Source: Author's research.

In the northern village of Hoài Thị, the more noticeable increase in the size of wedding banquets over three-and-a-half decades and the greater attendance at events with gifts reflects a very different social capital configuration than in Khánh Hậu. More specifically, Hoài Thị villagers have made significantly greater effort to organise voluntary associations and to revitalise patrilineages in order to strengthen social ties which involve obligations at life cycle ceremonies and death anniversaries.

In 2005, when comparative data on kinship and voluntary association ties in the two communities were systematically collected, the striking differences in social relational configuration between Hoài Thị and Khánh Hậu became evident. More specifically, within the kinship domain, the kinship network in Hoài Thị was much denser than in Khánh Hậu. Due to the relatively high degree of community endogamy across generations, every Hoài Thị villager was related consanguinally or affinally to numerous others in the village (see Luong 2010:401-402). Of equal importance was the establishment or re-creation of numerous associations in Hoài Thị, a process which has intensified over the past two decades. They ranged from patrilineages to voluntary associations, the most important being same-age associations (hội đồng niên). Through these institutions, in which Hoài Thị villagers invested considerable time and financial resources, they strengthened their social networks and 
social capital - social capital as defined by Bourdieu as 'the aggregate of the actual or potential resources which are linked to possession of a durable network of more or less institutionalized relationships' (Bourdieu 1986:249). The strength of Hoài Thị villagers' social capital is partly reflected in the higher number of events involving gift exchanges which they attended.

\section{Kinship}

Hoài Thị patrilineages were revitalised from the 1980s onwards. They played an increasingly important role in both rites of solidarity and rites of passage. For example, at the village tutelary deity's procession during the village festival in the first lunar month, many lineages presented their offerings to the deity and had them carried in the procession in order to assert their identities. Many also organised the worship of lineage founders and established 'educationencouragement funds' (qũy khuyến học), recognising the educational achievements of students in their lineages. At funerals, patrilineages made their own offerings to deceased members and organised their male members in order to assist with funeral processions and grave digging. A Hoài Thị villager related how the patrilineage of her husband raised funds for funeral offerings:

Female interviewee: The [Nguyễn] Sỹ patrilineage specifies that the patrilineal kin who [according to customs] wear [white] mourning head bands would each contribute 10,000 [VND to the funeral gift from the patrilineage to the household of the deceased]. So, when the mourning head bands are distributed to a household, the household gives the money. Three bands, 30,000 VND; 2 bands, 20,000 VND. (Nguyễn Tiến Lộc's interview with Household 480 in Hoài Thị) $)^{5}$

In Khánh Hậu, the descendants of Nguyễn Huỳnh Đức organised themselves into the only patrilineage in the community, whose activities centred on the death anniversary of the lineage founder on the ninth day of the ninth lunar month. The activities of the Nguyễn Huỳnh patrilineage in Khánh Hậu were more limited in scope than those of the patrilineages in the village of Hoài Thị: it neither had an education-encouragement fund, nor was it actively involved in the

5 Nguyễn Tiến Lộc was a member of one of the two field teams in my research project. So were Tạ Hữu Dực, Nguyễn Anh Tuấn, Nguyễn Thị Nhung, and Huỳnh Ngọc Thu whose names are mentioned at the end of some other interview excerpts. 
funerals of its members. In the larger context of the Mekong delta, patrilineages were rarely established, and when they existed as in Khánh Hậu, the scope of their activities was considerably more limited than observed in the Red River of North Vietnam. The reciprocal obligations among the members of the same patrilineage in Hoài Thị in particular, and in the Red River Delta in general, strengthened their relations and enlarged their social capital.

\section{Non-kinship}

In Hoài Thị, the strengthening of kinship ties through patrilineages was a part of the larger institutional framework for enhancing social capital. Hoài Thị villagers had established numerous non-kinship associations with formal rules for mutual assistance. Most notable were the same-age associations (hội đồng niên). About two-thirds of Hoài Thi men between the age of 18 and 60 belonged to the sameage associations whose membership was village-bound. Same-age associations had strict rules regarding gifts and mutual assistance on major occasions in association members' households: wedding (a major collective gift to an association member), house construction, and funeral (of members, members' spouses and parents; with collective offerings and labour assistance at the ceremony). (Only 24 of the 319 Hoài Thị women in the 18-60 age range joined same-age associations.) One villager explained the importance of same-age association ties:

When asked about whether they were happy with the membership in the same-age association and whether the membership had led to a good amount of mutual assistance, the whole group concurred that a same-age association was better than a same-school-class association (hội đồng học). A same-school-class association did not bring together all the friends of the same age from the village. If the same-school-class association was formed among classmates from a senior secondary school, some members would be from other communes. Such fellow association members could not understand one another as well as childhood friends of the same age and from the same village. When one joined a same-age association, one's household, although having only one son, would have ten sons [from a same-age association with ten members]. When one's household had a house constructed, all association members would come to help without pay and need to be fed only. Even when an association member was absent, his younger or elder brother would come to help as a replacement [for the absent association member]. Or when a member's household had a wedding, fellow [same-age] association members came 
to help set up the banquet area. Those who worked away from the village and could not help before the main wedding day would make an effort to be at the wedding. (Fieldnotes of Tạ Hữu Dực about Household 383 in Hoài Thà)

The remaining voluntary associations in Hoài Thị, while less important than same-age associations, were numerous: educationpromotion associations (hội khuyến học), elderly male group at the communal house, elderly female Buddhist association, all-women incense-offering team (đội dâng hương), adverse-circumstance women's group with incense burners at the pagoda (nhóm bat hương), samemilitary-service association ( $h$ ộ đồng ngũ), same-circumstance women's associations (hội đồng tâm), alumni associations, same-occupation associations, parallel-verse singing (quan họ) club, spirit medium group (nhóm con nhang), and a retired state worker group. Male villagers participated more in the formal voluntary associations than their female counterparts (Figure 3) because, according to many female informants, married women had more domestic duties (including the care of children and grandchildren).

In contrast, voluntary association membership was much less common in Dinh hamlet of Khánh Hậu, ${ }^{6}$ despite a population size three times greater than Hoài Thị. In 2005, the number of voluntary association memberships for every 100 persons aged 16 or above was 112 among men and 70 among women in Hoài Thị, and 17 among men and 7.6 among women in Khánh Hậu (Figure 3). ${ }^{7}$ By 2012, this difference had widened. Specifically, in Hoài Thị, eight neighbourhood associations had been

6 Khánh Hậu also had a poetry club and traditional music club whose activities were partly sponsored by the local government. But relatively few Dinh hamlet residents were members of these clubs. The three Cao Dai temples in Khánh Hậu, however, formed three communities within which there was mutual assistance in the form of praying at funerals.

7 These statistical figures for villagers above the age of 16 do not include rotating credit associations, which involve mostly households and household budgets. There was an average of 0.56 rotating credit association memberships per household in Dinh hamlet of Khánh Hậu compared with 0.4 in Hoài Thị. In terms of gender, in the northern village of Hoài Thị, both men and women participated in credit associations, while in the southern community of Khánh Hậu, it was mainly women who participated in credit associations. Since data on credit association membership were collected not at the individual level but at the household level, they are not used in the calculation of the number of association memberships per 100 adult men or 100 adult women.

In both Hoài Thị and Khánh Hậu, there were also state-organised associations, such as women's association, peasant association, elderly association, youth association, and trade unions (only in Khánh Hậu). In 2005, the rate of membership for every 100 residents above the age of 16 was 44 in Hoài Thị and 11 in Khánh Hậu for women's association; and, for other state-organised associations, 84 for both men and women in Hoài Thị, and 14 for men and 9 for women in Khánh Hậu. 
formed, covering 37 per cent of village households. Women going through the same Buddhist ceremonies (lễ quy y) had also formed mutual aid associations. Membership of the Buddhist association also increased from 75 in 2005 to 157 in 2013. The quan ho club membership doubled from 22 to 44. Declining membership of same-circumstance women's associations (hội đồng tâm) was due to their transformation into rotating credit associations, requiring contributions beyond the capacity of a number of members. The number of other voluntary association ties remained essentially unchanged. In general, the number of voluntary association ties per 100 adults in Hoài Thị increased from 2005 to 2012, while it did not increase in Khánh Hậu. The difference between two communities in voluntary association membership thus widened during this seven-year period.

Table 2: Voluntary association membership in Hoài Thị and Dinh hamlet of Khánh Hậu, 2005.

\begin{tabular}{|l|r|r|}
\hline & Hoài Thị & Khánh Hậu \\
\hline Population & 1,032 & 2,894 \\
\hline Association membership & & \\
\hline Communal house association/group & 41 & 42 \\
\hline Buddhist (prayer) association & 75 & 40 \\
\hline Ritual teams & 48 & 7 \\
\hline Spirit medium group & 8 & 6 \\
\hline Cao Đài children's team & & 6 \\
\hline Education-promotion association & 86 & 2 \\
\hline Same-military-service association & 41 & 13 \\
\hline Same-occupation association/group & 7 & \\
\hline Same-age association & 240 & \\
\hline Same-circumstance women's association & 45 & 14 \\
\hline Adverse-circumstance women's group & 21 & 9 \\
\hline Alumni association & 24 & \\
\hline Retired state worker group & 14 & 58 \\
\hline Quan ho singing club & 22 & \\
\hline Gymnastics club & & \\
\hline Traditional medicine philanthropy group & 100 & \\
\hline Rotating credit association & & \\
\hline
\end{tabular}

Source: Author's research. 


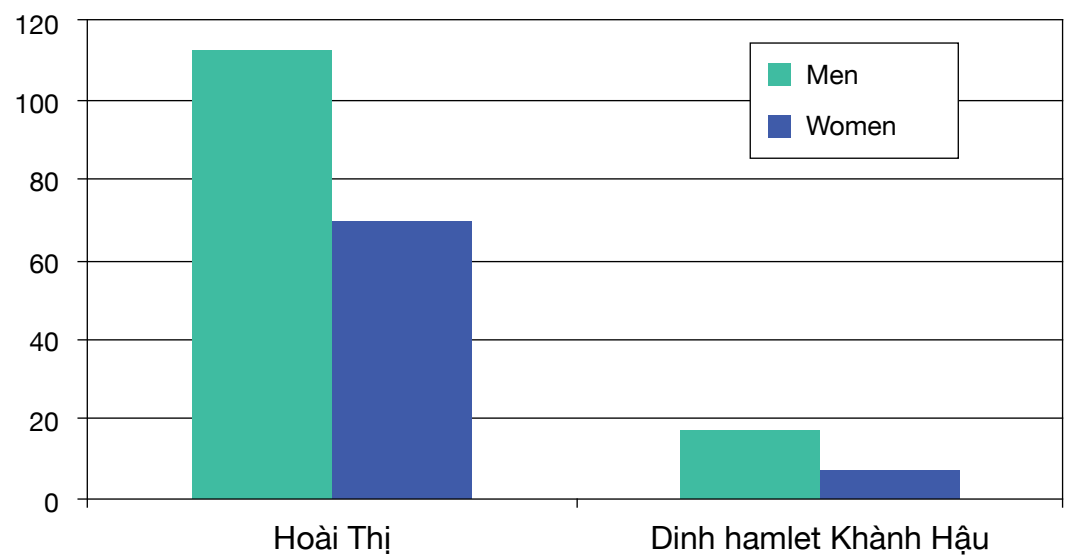

Figure 3: Voluntary association membership - number of memberships per 100 residents above the age of 16 in 2005. Source: Author's research.

The northern-southern difference in social relational configuration is a major feature not only in the rural landscape, but also in big cities such as Hà Nội and Hồ Chí Minh City. In Hà Nội, numerous samevillage associations ( $h$ ọi đồng hương) exist among people born and raised in somewhat distant villages in rural northern Vietnam, but in Hồ Chí Minh City, same-village or even same-commune associations among people migrating from rural southern Vietnam are unheard of. Even same-district associations are rare. Only same-province associations exist with very limited membership among people coming from the same province. While southerners do draw upon their ego-centred informal networks in urban contexts, northerners establish formal voluntary associations much more often.

If the high frequency of endogamous marriages rendered kinship ties in Hoài Thị multiplex in that the same two persons had different kinship roles vis-à-vis each other, depending on the tracing path (see Luong and Diệp Đình Hoa 2000:50-51), the formation of numerous voluntary associations, mainly in the past two decades, rendered social relations in Hoài Thị considerably more so. At major events such as weddings and funerals, many villagers had to present multiple gifts, many through their associations, because of these villagers' multiple relations to the household with such an event. In the context of intricately tight 
intra-village social networks and multiplex relations, it was difficult for any Hoài Thị household not to be fairly heavily involved in gift exchanges within the village.

From a diachronic perspective, the proliferation of voluntary associations accounted for an important part of the significant increase in the number of guests at such ritual events as death anniversaries and weddings in Hoài Thị, as explained by a villager:

Male interviewee: When I got married, we served about 35 trays of food [to about 175 guests]. [In those days] ... a wedding was attended by close relatives like first patrilineal cousins. Nowadays, [given the] same-age and same-school-class associations (hội đồng niên and hội đồng $h o c)$, invitations are sent out to a larger number or even to the entire village ... Not in my day ... It is only in the past few years when sameage associations proliferate, [there are] more wedding invitations. (Nguyễn Anh Tuấn's interview with Household 412 in Hoài Thà)

From a synchronic perspective, both the tighter kinship network in Hoài Thị than in Khánh Hậu and the proliferation of social ties through voluntary associations in Hoài Thị also underlay the more frequent attendance of Hoài Thi villagers at ritual events with gift exchanges. The larger number of events attended by studied Hoài Thị households reflects their generally larger social capital by which, as discussed below, they successfully mobilise material assistance on numerous occasions, ranging from job introduction (heavy concentration of villagers with non-agricultural incomes in the alcohol retail trade and in the construction industry in Hà Nội) to easier access to interest-free loans and to house construction in Hoài Thị itself.

The material assistance mobilised through social capital can be examined in greater depth through three cases: one well-off household in Khánh Hậu in 2006, and two relatively poor households, one in Khánh Hậu and one in Hoài Thị, undertaking household renovation in 2003 and 2005 respectively. Both of the poor households were in the second (below-average) income quintile in their respective communities, with the Hoài Thi household earning an annual per capita income of 4.7 million VND (\$317 USD), compared with 3.7 million VND (\$250 USD) in Khánh Hậu. The Khánh Hậu household received house construction gifts from only 11 households, worth 1 million VND (\$63 USD), while the Hoài Thị household received cash 
gifts from 106 households ( 85 from Hoài Thị) totalling 5.1 million VND (\$328 USD) on the occasion of its house renovation in 2003. These gifts added to the flow of interest-free loans for house construction (see below), enabling the Hoài Thị household under analysis to spend more on its house renovation than otherwise possible. In Hoài Thị, cash gifts and labour contributions came not only from kin and neighbours, but also from same-age association members, among other people whose social ties were formed or strengthened in the past two decades.

Among better-off Hoài Thị villagers, material assistance for the purchase of property and house construction was also quite substantial. A 37-yearold trader in Household 379, whose per capita income of 45 million VND $(\$ 2,300$ USD) in 2012 placed it in the top income quintile in Hoài Thị, related the material assistance that he had received:

When I had the house built in 2006, it cost 260 million VND $(\$ 16,227$ USD). My friends lent me a good part of the money, interest-free ... When I asked a friend for a loan of ten million VND (\$625 USD), he told his wife to get a tael of gold and gave it to me. A tael of gold was 19 million VND (\$1,186 USD) at that time. He said, 'How come only ten million VND? Take this. Give the house a good paint instead of leaving it unpainted ...' I chose to pay him back in three instalments, two-tenths of a tael, half a tael, and three-tenths of a tael. He said, 'No hurry. Take your time and make sure that you have enough money for other things.' When I bought a piece of land in the village, 85 square metres, for over 700 million VND (\$35,700 USD) later, I had to borrow over 300 million VND from my friends, all interest-free. 100 million VND from one friend, and scores of million VND from each of some other friends. And \$3,000 USD from my elder brother's daughter. (Excerpt from Hy V. Luong's interview with Household 379 in June 2014)

The reciprocal gift/labour exchange and interest-free loans allowed Hoài Thị villagers in particular, and northern Vietnamese rural dwellers in general, to build more expensive brick houses, even when they had very limited resources of their own. In contrast, in the southern Mekong Delta, many poor rural dwellers constructed simple and less expensive houses with thatched roofs, wooden walls and earthen floors. 
Because of the aforementioned difference between Hoài Thị and Khánh Hậu in social capital configuration, despite the higher annual per capita income in Khánh Hậu than in Hoài Thị (31 million VND ( $\$ 1,482$ USD) versus 23 million VND ( $\$ 1,094$ USD)), in 2012 the average number of people from whom surveyed households could borrow at least five million VND interest-free for at least one month was 15 in Hoài Thị and 5.5 in Khánh Hậu. In other words, social capital could be mobilised more easily in Hoài Thị than in Khánh Hậu.

However, social capital is a double-edged sword (Portes 1998; Geertz 1963). It can be mobilised for the purpose of resolving various problems in daily life. But it also involves obligations to people in one's social network. In the context of lower per capita income in the northern village of Hoài Thị than in the southern community of Khánh Hậu, and in the face of larger numbers of kinship and non-kinship ties with gift obligations in the former, Hoài Thị villagers have introduced rules and practices for limiting ritual expenditures and gift expenses. By 2012, beer flowed without limit at death anniversary feasts and wedding banquets in Khánh Hậu, while in Hoài Thị, the number of beer cans offered at ceremonies was restricted. As cash gifts at weddings minimally covered the cost of the meal, these usually amounted to 100,000 VND (about \$5 USD) in Hoài Thị in 2012 in contrast to 200,000 VND (about \$10 USD) in Khánh Hậu. Despite the larger number of events attended by Hoài Thị villagers, the annual per capita spending on ritual events such as weddings, funerals, death anniversaries, among others, remained lower in Hoài Thị than in Khánh Hậu, both in 2005 and in 2012 (see Table 2). Hoài Thị villagers succeeded in holding down their gift and ritual expenses and simultaneously increasing their social capital, more than people in Khánh Hậu. 
Table 3: Per capita spending on gifts in 2005 and 2012 in million of VND (in constant 2012 value of VND). ${ }^{8}$

\begin{tabular}{|c|c|c|c|c|}
\hline \multirow[b]{2}{*}{ Year } & \multicolumn{2}{|c|}{ Hoài Thị } & \multicolumn{2}{|c|}{ Khánh Hậu } \\
\hline & 2005 & 2012 & 2005 & 2012 \\
\hline $\begin{array}{l}\text { Number of surveyed } \\
\text { households in community }\end{array}$ & $(n=247)$ & $(n=280)$ & $(n=367)$ & $(n=411)$ \\
\hline Annual per capita income & $\begin{array}{c}14.72 \\
(\$ 450 \text { USD) }\end{array}$ & $\begin{array}{c}22.97 \\
(\$ 1,094 \text { USD) } \\
\end{array}$ & $\begin{array}{c}16.785 \\
(\$ 513 \text { USD) }\end{array}$ & $\begin{array}{c}31.12 \\
(\$ 1,482 \text { USD) } \\
\end{array}$ \\
\hline $\begin{array}{l}\text { Annual per capita } \\
\text { spending on gifts }\end{array}$ & $\begin{array}{c}1.99 \\
\text { (\$61 USD) }\end{array}$ & $\begin{array}{c}2.49 \\
\text { (\$119 USD) }\end{array}$ & $\begin{array}{c}2.22 \\
(\$ 68 \cup S D)\end{array}$ & $\begin{array}{c}3.1 \\
(\$ 148 \text { USD) }\end{array}$ \\
\hline $\begin{array}{l}\% \text { of income spent on } \\
\text { gifts at ceremonies }\end{array}$ & $13.5 \%$ & $10.8 \%$ & $13.2 \%$ & $10 \%$ \\
\hline
\end{tabular}

Source: Author's research.

\section{Class and Social Capital}

Although ethnic Vietnamese of all social strata attach great significance to social connections or social capital, opportunities for maintaining and expanding social capital are not equally available to all members of society. While the poor can express their sentiment through advice, support, and sociality, those with wealth and political power, forming a dominant class, are in a much stronger position to cultivate social relations by organising more events, inviting more people to these events, and by offering financial support and interest-free loans to people in their social networks.

Survey data (Table 4) indicate that in 2012, in both communities, the average net per capita expenditure on rituals (mostly on weddings, funerals and death anniversaries) and gifts at these rituals hovered in the range of 1.75 to 2.5 million VND for the first (lowest), second, third, and fourth income quintiles. These expenditures are both

8 As average incomes rose during the period between 2005 and 2012, gift and social relational expenditures per capita, controlled for inflation, also increased in absolute amount (by 25 per cent in Hoài Thị and 40 per cent in Khánh Hậu). There is thus no evidence that, as wealth increased, villagers became less involved in the gift economy. However, in both communities, the percentage of income spent on gifts and social relations dropped from over 13 per cent in 2005 to the range of 10 per cent in 2012. The declining percentage of income spent on gifts and social relations probably resulted from a greater investment in education, among other items. In our general household survey in 2000, with 207 households in Hoài Thị and 340 in Khánh Hậu, we did not ask about gift/ritual spending. Data are only available for 40 households in Hoài Thị and 70 households in Khánh Hậu in 2000 on the basis of a different research instrument, making 2000 data not strictly comparable to 2005 and 2012 ones. 
for gifts in attending those rituals in other households, and for net expenditures for the organisers, after deducting the cash gifts from guests. Many poor households in the bottom income quintile in both communities had to spend annually (almost) as much per capita on ritual event gifts as those in the middle income quintile in order to maintain their social relations. For households in the bottom income quintile, these ritual expenses to maintain social capital amounted to an average of 23 per cent of income in the southern community of Khánh Hậu and 31 per cent in the northern village of Hoài Thị. At the opposite end, although households in the top income quintile clearly spent more on ritual expenses to cultivate social relations and obtained more benefits from their larger social capital (reflected in the much larger number of possible interest-free loans), on average, their ritual expenses amounted to less than 10 per cent of their income.

Table 4: Per capita income and ritual expenditure by income quintile, 2012 (income and expenditure in million of VND; USD equivalents appear in parentheses).

\begin{tabular}{|c|c|c|c|c|c|c|}
\hline \multicolumn{2}{|c|}{ Income quintile } & \multirow{2}{*}{\begin{tabular}{c|}
$\begin{array}{c}1 \\
\text { (lowest) }\end{array}$ \\
7.74 \\
$(\$ 369)$
\end{tabular}} & \multirow{2}{*}{\begin{tabular}{|c|}
2 \\
15.12 \\
$(\$ 720)$ \\
\end{tabular}} & \multirow{2}{*}{$\begin{array}{c}3 \\
19.33 \\
(\$ 920) \\
\end{array}$} & \multirow{2}{*}{$\begin{array}{c}4 \\
25.15 \\
(\$ 1,196)\end{array}$} & \multirow{2}{*}{$\begin{array}{c}\begin{array}{c}5 \\
\text { (highest) }\end{array} \\
47.4 \\
(\$ 2,257)\end{array}$} \\
\hline Hoài Thị & a. Per capita income & & & & & \\
\hline & $\begin{array}{l}\text { b. Per capita ritual } \\
\text { expenditure }\end{array}$ & $\begin{array}{c}2.4 \\
(\$ 114)\end{array}$ & $\begin{array}{r}1.95 \\
(\$ 93)\end{array}$ & $\begin{array}{c}2.26 \\
(\$ 108)\end{array}$ & $\begin{array}{c}2.48 \\
(\$ 118)\end{array}$ & $\begin{array}{l}3.35 \\
(\$ 160)\end{array}$ \\
\hline & $\begin{array}{l}\begin{array}{l}\% \text { of income spent on } \\
\text { ritual expenditure }\end{array} \\
\end{array}$ & $31 \%$ & $13 \%$ & $12 \%$ & $10 \$$ & $7 \%$ \\
\hline & $\begin{array}{l}\text { Average no. of possible } \\
\text { interest-free loans at } \\
\text { or above } 5 \text { million VND } \\
(\$ 238)\end{array}$ & 10.7 & 9.9 & 16.4 & 15.8 & 21.7 \\
\hline \multirow[t]{4}{*}{ Khánh Hậu } & a. Per capita income & $\begin{array}{c}8.66 \\
(\$ 412)\end{array}$ & $\begin{array}{c}16.4 \\
(\$ 781)\end{array}$ & $\begin{array}{c}23.22 \\
(\$ 1,106)\end{array}$ & $\begin{array}{c}32.1 \\
(\$ 1,529)\end{array}$ & $\begin{array}{c}75.22 \\
(\$ 3,582)\end{array}$ \\
\hline & $\begin{array}{l}\text { b. Per capita ritual } \\
\text { expenditure }\end{array}$ & $\begin{array}{l}1.97 \\
(\$ 94)\end{array}$ & $\begin{array}{l}1.75 \\
(\$ 83)\end{array}$ & $\begin{array}{l}2.22 \\
(\$ 106)\end{array}$ & $\begin{array}{c}2.4 \\
(\$ 114)\end{array}$ & $\begin{array}{c}7.2 \\
(\$ 343)\end{array}$ \\
\hline & $\begin{array}{l}\% \text { of income spent on } \\
\text { ritual expenditure }\end{array}$ & $23 \%$ & $11 \%$ & $9.6 \%$ & $7.5 \%$ & $9.6 \%$ \\
\hline & $\begin{array}{l}\text { Average no. of possible } \\
\text { interest-free loans at } \\
\text { or above } 5 \text { million VND } \\
\text { (\$238) }\end{array}$ & 2.3 & 3 & 5.8 & 3.4 & 11.7 \\
\hline
\end{tabular}

Source: Author's research. 
Why did the poor in both Khánh Hậu and Hoài Thị tend to accept the burden of ritual expenses, which took up a relatively high percentage of their income, and which caused considerable tension in intrahousehold relations? As seen in two of the three cases below, the burden of ritual expenses was accepted by households in order to reciprocate assistance received in the past (at weddings and funerals, among other occasions) and to maintain their social relations, which would increase the likelihood of future assistance from people and households in their networks.

In 2005, Household 91 in Khánh Hậu comprised a 73-year-old woman living with her granddaughters, aged six and 12. Household income was derived mainly from the remittances from her youngest son and daughter-in-law (the parents of her granddaughters) who had received 1.5 hectares of cultivable land in the Plain of Reeds as a part of the resettlement of landless cultivators in the late 1980s. The elderly woman's mother had a long ancestral root in Khánh Hậu, while her father came from a neighbouring commune. Her deceased husband's family had settled in Khánh Hậu for at least one generation. Her daughterin-law came from a neighbouring commune located in Tiền Giang Province. In 2005, the daughter-in-law returned to Khánh Hậu during slack seasons to help take care of the two granddaughters, while the son stayed in their new village to take care of the land. With an annual per capita income of 3.1 million VND (\$196 USD) in 2005, Household 91 fell into the bottom income quintile in Khánh Hậu. However, it had ancestral worship duties to five deceased persons, including the elderly woman's husband, parents-in-law, and grandparentsin-law. Due to its limited financial resources, it annually organised only one big death anniversary banquet (that of the elderly woman's husband), which cost about 2 million VND (\$125 USD). The elderly woman in Household 91 reportedly attended 53 events in a 12-month period in 2005-06, presenting gifts worth approximately 2.3 million VND (about one-quarter of the total income of this household, equivalent to $\$ 146$ USD). They included 26 death anniversaries (mostly among the elderly woman's relatives and acquaintances in Khánh Hậu), 12 weddings, eight funerals, four birth celebrations, three visits to sick acquaintances, and one house construction party. The overwhelming majority were organised by the elderly woman's relatives, children-in-law's parents, and neighbours. Although some of the elderly woman's gift money came from remittances from her 
oldest son living in another province and occasional gifts from her four married daughters in Khánh Hậu, the bulk of the gift expenses, as well as more than half of the big death anniversary expenses, had to be covered by her youngest son and daughter-in-law. (It is customary for youngest sons in the southern third of Vietnam to inherit their parents' houses, a greater portion of their parents' land, and to assume a greater responsibility for ancestral worship, in contrast to the pattern in the Red River Delta, where the oldest son tends to assume this role.) The gift burden on the youngest son and his family was a major source of conflict between the elderly woman and her daughter-in-law, to the point that they were barely on speaking terms with each other during our fieldwork in 2005:

Mrs C. [daughter-in-law in Household 91] said that she would be ready to pass on her family affairs to whoever was willing to take them over ... that the family had no savings year in, year out ... that money was heavily spent on ritual gifts ... [She referred to Mrs K., her mother-in-law, in the front room with] another reminder [to her] about the need to go to the funeral of Mr Tư in Thủ Tủu [hamlet]. Mrs Sáu [a neighbour of Mrs C.] also made a similar complaint that it was a heavy burden getting married to a youngest son and living in a family with ancestral worship obligations, and that earnings were heavily spent on ritual banquets.

Mrs Sáu went home to go to bed. I continued talking to Mrs C. until 10 p.m. Mrs C. complained and talked about all sorts of things centring on the conflict with her mother-in-law and the costly ritual banquet expenses in a household with ancestral worship duties ... Her motherin-law [reportedly] spent a lot of money [on gifts to be brought to ritual banquets]. [Mrs C. said] no matter how hard she worked, money was always short, and that they were regularly in debt. Her mother-inlaw readily accepted invitations, and spent 100,000 VND on a wedding gift [above the normal figure of 50,000 VND for a wedding in 2005] and $50,000 \mathrm{VND}$ on a funeral gift. Occasionally, Mrs C. suggested [to her mother-in-law] to scale down the gifts. Her mother-in-law reportedly said that she could not behave like a dog. [When Mrs C did not give the money for a ritual banquet gift], the mother-in-law, after changing her clothes [to go to the banquet], kept repeating: 'Maybe I am a dog.'

Mrs K [the mother-in-law] would attend the funeral as the in-law of the deceased's in-law. Mrs K called Ms Sáu [nicknamed] the Fatso in to give the money, but Mrs C understood that it was her obligation to give the money to Ms Sáu. Mrs C. talked quietly to Mrs Sáu, and the latter left with no money. Mrs C left to visit a neighbour. 
Mrs K. [the mother-in-law] walked in and out of the house and told me: She [C.] did not care about funerals, as if I would not die [implying that $\mathrm{C}$. did not care about the future reciprocation of acquaintances at Mrs K.'s funeral] ... Mrs C said that [her mother-in-law] said that a gift of 50,000 VND was not adequate [at the funeral]. Because Mrs K. would go with the mother-in-law of her children, she reportedly wanted to give a 100,000 VND gift. (Fieldnotes of Nguyễn thị Nhung on Household 91 in Khánh Hậu in August 2005)

The large number of events attended by the elderly woman in Household 91 was due partly to her strong integration in the local social and kinship network, the need to reciprocate past gifts, given at her husband's funeral in 1994 and her five children's weddings over the years, the formal gift-exchange relations with her childrenin-law's parents, as well as the anticipated need for a good and large future funeral for herself attended by people in her network and those of her children, including the recipients of her ritual gifts. Despite its relative poverty, Household 91 had an extensive social and kinship network and thus more social capital than many richer households in Khánh Hậu. ${ }^{9}$

In 2005, Khánh Hậu Household 16 comprised five members, a couple (husband aged 44, and wife, 39), their two sons (aged 17 and 2), and the wife's mother, who was temporarily residing with them to help care for their two-year-old son. Although the husband was born elsewhere, due to his father's work assignment in another province, he had long-standing connections to Khánh Hậu, where his maternal grandfather had been a large and influential landowner before the political change in 1975, a change that adversely affected the maternal grandfather's landholding due to the new regime's collectivisation policy. The husband had numerous close relatives in Khánh Hậu, and the land on which his house was built was bequeathed by his maternal grandfather. The wife came from Tân Hội Đông, a neighbouring commune located in Tiền Giang Province. This household had

\footnotetext{
9 In 2012, the number of death anniversaries attended by the members of Household 91 increased to 34 , and the total ritual expenses to 8.75 million VND (\$417 USD), triple that of expenditure in 2005. (The ritual expenses per capita in this household were 2 million VND a year.) However, the tension between the mother-in-law and daughter-in-law subsided apparently due to the significant increase in the annual per capita income of the household to 33.6 million VND (\$1,600 USD) compared to \$196 USD in 2005 thanks to the greater agricultural income of the son and non-agricultural income of the daughter-in-law. The ritual and gift expenses of Household 91 took up only 6.25 per cent of the household income in 2012.
} 
0.45 hectare of land on which the husband worked, and the husband also helped the wife in her phở (beef noodle) business in the provincial capital of Tân An (6 kilometres away). Their annual per capita income of 3.1 million VND (\$210 USD) in 2005 put them in the bottom income quintile in Khánh Hậu. Despite the relatively limited income of the household, the husband had an extensive kinship network in Khánh Hậu, while his wife possessed her own in her native commune, as well as in Khánh Hậu, where one of her sisters had married into a Khánh Hậu family. Among the husband's close relatives were his parents and four brothers with their families in Khánh Hậu, one married sister in Khánh Hậu, and three sisters married to husbands in a neighbouring commune or in the nearby provincial capital. The husband also had a maternal uncle, some maternal aunts, and numerous first cousins on both his father's and mother's sides in Khánh Hậu. The wife had her parents and seven married siblings, as well as numerous aunts, uncles, and first cousins, in her native commune neighbouring Khánh Hậu. The husband and wife in Household 16 attended a total of 51 gift-exchange events in the 12-month period under study, including 25 death anniversaries, 12 weddings, two wedding-preparatory ceremonies, seven funerals, three birth celebrations, one visit to a sick acquaintance, and one other ritual. Among the 25 death anniversaries were four banquets held at the household of this husband's maternal uncle, each of which required gifts to be brought. ${ }^{10}$ As the husband was not the youngest son in his natal household and as his parents were alive and living with his youngest brother, he did not have any death anniversary to take care of. He also reportedly cut back on the number of death anniversaries attended in 2005 out of concern for the cost of gifts and the need to support his elder son's possible university education. But in 2005, this household still spent 3.1 million VND a year (\$210 USD), about one-fifth of the total family income, on gifts for 51 events organised by other households. This resulted from the couple's strong integration into the local social networks in Khánh Hậu and in a neighbouring commune.

10 As a reflection of his wealth, the maternal uncle organised four death anniversary banquets with significantly overlapping guest lists (about 100 guests at the death anniversary of his father; 40 at that of his mother; and 40 and 20 at those of his two sons). In Khánh Hậu, despite the widely reported pattern of dividing death anniversary duties among siblings and close relatives, it was not uncommon for a household to hold many death anniversary banquets in a year if it had the economic means to do so. 
In 2009, the husband in Household 16 passed away. The wife had to sell a part of the family's landholding to pay off the husband's medical expenses, and her sister-in-law took over the phở (beef noodle) business. In 2012, the wife in Household 16 worked for the sister-in-law in the morning and the early evening. The wife also peddled roasted rice paper (bánh tráng nướng) in the afternoon to earn extra income in order to bring her monthly income to 3 million VND (\$143 USD). With the elder son being an officer in the armed forces and her mother returning to the neighbouring commune, Household 16 had only two members. Its annual per capita income rose to 18 million VND (\$857 USD), putting the household in the second income quintile (below average). In 2012, despite having a nine-year-old child to support, Household 16 had to spend 2.7 million VND (\$129 USD, or 7.5 per cent of total household income) on ritual gift expenses, including at 19 death anniversaries. The wife in Household 16 talked about this ritual expense burden and the need to reciprocate people who had made cash gifts during her husband's illness and later at his funeral:

Interviewee: I sell [roasted rice paper] in Khánh Hậu to earn some extra money in the afternoon [besides assisting my sister-in-law with her phở and beefsteak business]. It costs a lot of money to cover ritual feast expenses and gifts ... So many of them. Cash gifts, for example, on the occasion of month-old celebrations (đầy tháng) and first birth days (thôi nôi) for kids. Next month, there will be two of these events for my husband's niece and nephew [sister's children]. I already made a 200,000 VND gift when the baby was born. Next month, 200,000 VND [\$9.52 USD] more for his month-old celebration. My husband used to take care of such events. Now I have to deal with them all ... Gifts for nieces and nephews have to be 200,000 VND. For other kids, 100,000 VND ... I also have to visit sick people in my network and that of my husband ... Because when my husband was sick, they came to visit and gave gifts. They gave 50,000 VND, and now when I visit a sick person in their families, I have to give 50,000 VND. For funerals, the gift has to be 100,000 VND. 50,000 VND looks miserly.

Interviewer: When your husband passed away, did you accept cash gifts? 
Interviewee: Yes. The cash gifts were sufficient to cover funeral costs ... The gifts ranged from 20,000 VND, 30,000 VND, 50,000 VND to 100,000 VND. Money could buy more in those days [in 2009, thus gifts had a comparatively lower value]. The funeral gifts amounted to over 30 million VND [\$1,650 USD].

Interviewee: I have to wake up at 4 a.m. in the morning. I have not had any rest until now [interview taking place at the phở restaurant owned by the interviewee's sister-in-law] ... Now, I am roasting rice paper and going to walk around the community to sell it. I work so hard.

Interviewer: Any siesta?

Interviewee: No. I work hard to earn some money to host a death anniversary feast for my husband.

Interviewer: When can you go home?

Interviewee: Around 5 p.m. I go home to take a shower and burn incense for my husband, and return here to work until 8:30 in the evening, during which I also wash clothes for my sister-in-law and her children.

Interviewer: No washing machine?

Interviewee: No, all by hand.

Interviewee [crying]: It is a lot of hard work to earn money. But my sister-in-law provides meals for me and my son every day ... A lot of hard work. I sell roasted rice paper to earn some extra money. Many times, in roasting the rice paper, I cry and cry ... I try to earn some extra money and try to save for my son ... I do not spend a lot of time during the day at home, because I feel so sad there ... Now, I roast about 20 rice papers in over an hour, and then go around peddling them, and earn 20,000 VND for the work [one-fifth of her daily income]. (Huỳnh Ngọc Thu's interview with Household 16 in November 2012)

Some poor and elderly people, as in Household 543 in Hoài Thị, decided not to accept death anniversary invitations in order to hold down their ritual gift expenditures. Household 543 in Hoài Thị, comprising an elderly couple, had an annual per capita income of 1.33 million VND (\$63 USD in 2012) mainly from government assistance, which put them 
among the poorest in the village of Hoài Thi.. ${ }^{11}$ They spent nothing on ritual gift expenses in 2012, as they felt that they could not afford to. Unlike most other Hoài Thi villagers, they also believed that they could not borrow 5 million VND interest-free from anybody in their social network. The elderly couple's social capital and the ability to mobilise it in the form of interest-free loans was greatly diminished due to their lack of spending on ritual expenses. This lack of spending on ritual expenses reflects the extreme poverty of this elderly couple (in contrast to Household 91 in Khánh Hậu, the first case earlier discussed). In 2014, when I asked about their lack of spending on ritual expenses, the elderly couple talked at length to me about their embarrassment in not being able to maintain their ritual and social relation obligations:

HL: Do you still give cash gifts at death anniversaries, or are they waived, as you are now over 80 years old?

Husband: For the elderly over the age of 80 , the cash gift is only 50,000 đồng (\$2.40 USD). It is all right not to give a cash gift [given the age], but it looks better if one is given.

Wife: He does not give cash gifts at death anniversaries. That is why he said, 'if one is given'. Without a cash gift, we come and stay for a short time ... It feels embarrassing.

HL: When the two of you turned 80, did your children organise a feast for you and your acquaintances?

Husband: No, they did not ... if I organised a death anniversary feast for my father, inviting other people, then [I would feel better] attending the death anniversaries organised by the latter ... As I do not host a feast on my mother's or father's death anniversary, I do not go to death anniversaries that much.

11 The social welfare net in Vietnam has expanded noticeably in the past few years, well beyond the anti-poverty program started in the 1990s. New programs include modest assistance of 2.16 million VND (\$103 USD) a year and a free health insurance card to the elderly from the age of 80 onwards and to other single elderly without much income and without children as a source of support; and assistance to disabled people, including victims of Agent Orange, with annual payments varying with the degree of disability (see Lưu Quang Tuấn 2012:13-14). In 2012, the elderly couple in Household 543 had one person with a minor mental problem who was eligible for 2.18 million VND (\$103 USD a year) under the program of assistance to the disabled. In summer 2014, the government assistance to this couple had tripled to 6.54 million VND (\$310 USD) because the disability assistance amount was doubled, and because the other person qualified for assistance provided to people aged 80 years and older. 
Wife: My children do not organise a longevity meal for us [and our acquaintances] ... When other elderly people have longevity feasts, I do not dare to show up despite the invitations ... My husband and I are old. We are not able to host a death anniversary feast [for either parent of his]. Neither are our children. The longevity celebrations [for us] are less necessary than death anniversary feasts. If we are not able to host a death anniversary feast, there is no need to talk about a longevity celebration ... It all boils down to the eldest [son]. If the eldest son took the initiative, the three younger sons would follow and contribute ... If the eldest said that I would organise a longevity celebration for the parent, no way would the other children dare not to move in tandem ... It is embarrassing not to be able to host an annual death anniversary for a parent [of my husband]. Embarrassing not to be able to do what other households have done ... My first cousin T. [in the village] hosts a feast on the occasion of the death anniversary for my uncle [T's father], and invites me ... Another cousin of mine going to the same event asks me to go with her. I have decided not to go, but do not want to go into details with her ... It would be a shame for me to say that because of our inability to host a death anniversary feast, I cannot go ... I feel miserable ... [Husband tells her to stop talking about this problem.] It is all right to stop talking about this issue, but we would be the laughing stock of the village if we just go and eat at death anniversary events without being able to host one at our place. We end up cutting ties with relatives, close or far. We do not dare to go to those events. Except for one recent event, I did show up. People filled my bowl with foods, but I felt so bad inside that I could not really eat. (Author's interview with Household 543, June 2014)

The cases discussed above, and the lack of significant variation in the average ritual gift spending per capita among the four lower income quintiles in both communities, indicate that the relation between ritual spending and household income is far from being linear. My preliminary analysis suggests that besides household wealth, many factors affect ritual and ritual gift spending:

a. Sibling rank: In Hoài Thị, the eldest son assumes official responsibility for ancestral death anniversaries and social relations with relatives, although he may allow younger siblings to host some death anniversary feasts. In Khánh Hậu and in southern Vietnam at large, it is the youngest son who is supposed to assume such a responsibility. As the youngest son of Household 91 in Khánh Hậu is not resident, his wife felt this responsibility as a heavy burden. 
In contrast, without official responsibilities for family rituals and social relations with relatives, the male head of Khánh Hậu Household 16, as well as the male trader in Household 379 and the elderly male head of Household 543 in Hoài Thị, had lower ritual and social relation spending than those with such responsibilities.

b. Stage in life cycle:

i. People in their 20s tend to have many friends getting married, leading to higher wedding gift expenditure.

ii. People in their 30s tend to have fewer ritual gift obligations in general (the trader in Household 379 in Hoài Thị as an example).

iii. People in their 40s and 50s tend to be responsible for the weddings of their children, and to reciprocate the wedding gifts received at these events with similar gifts at friends' children's weddings. Those who experience the death of a parent/s also begin assuming death anniversary duties.

c. Degree of integration into local social networks: Hoài Thị villagers have close-knit social networks and tend to be well integrated in their community. In contrast, in Khánh Hậu and many southern communities, where there is a higher degree of geographical mobility, a number of newcomers in a community tend to be not well integrated and to have fewer obligations (see also Luong 2010:417-418).

Those factors complicate the relation between household income and social capital and ritual expenditure; this relation is not statistically linear among lower- and middle-income households. The highest income households in both Hoài Thị and Khánh Hậu tend to spend more lavishly on social relations in order to strengthen their social capital, which results in significantly greater assistance actually or potentially received (see the data on interest-free loans in Table 4). However, the incapacity of the poor to spend much at all on social capital cultivation - as reflected in the case of the elderly couple in Household 543 in Hoài Thị — weakens social ties and results in less assistance received in the form of interest-free loans. 


\section{Conclusion}

How can we explain the difference in social capital configuration between Hoài Thị and Khánh Hậu, a difference that, I think, is characteristic of the difference between the northern and southern Vietnamese lowlands in general? The difference in social capital configuration lies not only in the greater efforts of Hoài Thị villagers in cultivating and formalising social relations (partly through the establishment of patrilineages and voluntary associations), but also in the greater return from these efforts, as reflected in the considerably greater sources of interest-free loans that can be tapped by Hoài Thị villagers than by those in Khánh Hậu.

Beyond Vietnam, the importance of social connections has been attributed to shortages in political economy and formal institutional weakness, leading to greater uncertainty and people's reliance on social connections in order to reduce uncertainty (Guthrie 1998; Walder 1986). Can the greater efforts of northern Vietnamese to cultivate social relations result from more shortages of goods and services and greater institutional weaknesses in northern Vietnam than in southern Vietnam? There is no evidence that Hoài Thị villagers have recently faced more shortages and greater uncertainty due to institutional weaknesses than the people of Khánh Hậu. With the strong economic growth in Bắc Ninh Province in recent years, Hoài Thị villagers have no trouble earning steady and fairly good incomes in the private or informal sector, and finding quality goods and services. There is no clear evidence either that the conformity to institutional rules is weaker in northern Vietnam than in southern Vietnam, leading to greater uncertainty in the sociopolitical environment and, consequently, to greater reliance on social connections for problem solving in northern Vietnam. Beyond the case of Vietnam, Japan seems to have much stronger formal institutional frameworks than Vietnam and does not have any shortage of goods and services. Yet gifts and social connections remain a very important part of the Japanese sociocultural fabric and political economy. I would argue that it is simplistic to attribute the importance of social connections solely to shortages of goods and services and institutional weaknesses. A strictly institutional explanation of the importance of gifts and social capital would fail to do justice to their salience in Vietnamese or Japanese sociocultural life and political economy. I think that we also 
need to take into account different enduring models of and for reality in northern and southern Vietnam, enduring models that account not only for the greater investment in social capital, but also, among other things, for the greater strength of patrilineal descent in northern Vietnam than in southern Vietnam (cf. Yang 2002 in Yang's debate with Guthrie in the Chinese context).

I would suggest that the enduring northern Vietnamese model for social reality involves a greater formalisation of social relations, both in terms of obligations and organisation (patrilineage and voluntary associations, with their explicit rules), and, as a reflection of comparatively less commercialisation in a rural community, more mutual assistance in time, labour, and interest-free loans (see Table 4) and less monetary expenditure per event. In Hoài Thi and the Red River Delta of northern Vietnam in general, at the community level, social relations, whether kinship-based or not, also tend to be more centripetal, leading to considerably tighter social networks within the community. In contrast, in Khánh Hậu, social relations are less formalised in terms of organisation and obligations, with less mutual assistance in time, labour, and interest-free loans. In Khánh Hậu and the Mekong Delta of southern Vietnam in general, at the community level, kinship and non-kinship relations tend to be more centrifugal, leading to looser social networks within the community. In Khánh Hậu, ritual events such as death anniversaries are organised in a freeflowing spirit, with less effort made to control costs, leading to higher expenses per event both for organisers and gift-bearing participants. Thus, while social relations (quan hệ) are important in the social fabric of both northern and southern Vietnamese communities, they take on different configurations, with varying degrees of effectiveness in mobilisation. It is possible that the different social capital configurations and enduring models for reality in the Red River Delta and the Mekong Delta of Vietnam result from the long-standing greater spatial mobility in the latter in a frontier context, which renders formal organisations less stable and less effective. We can attempt to analyse long-term historical and environmental reasons for the difference in the model for reality between the northern Red River Delta and the southern Mekong Delta in Vietnam (see, for example, Rambo 1973). But it is not clear that this difference can be reduced to short-term differences in political economy and institutional contexts. 


\section{References}

Bourdieu, Pierre 1986, 'The Forms of Capital', in John Richardson (ed.), The Handbook of Theory and Research for the Sociology of Education, Greenwood Press, New York, pp. 141-158.

Geertz, Clifford 1963, Peddlers and Princes, University of Chicago Press, Chicago.

Gold, Thomas, Douglas Guthrie and David Wank 2002, 'An Introduction to the Study of Guanxi', in Thomas Gold, Douglas Guthrie and David Wank (eds), Social Connections in China: Institutions, Culture, and the Changing Nature of Guanxi, Cambridge University Press, Cambridge, pp. 3-20.

Guthrie, Douglas 1998, 'The Declining Importance of Guanxi in China's Economic Transition', The China Quarterly, vol. 154, pp. 254-282.

Henry, James 1964, The Small World of Khánh Hậu, Aldine, Chicago.

Hickey, Gerald 1964, Village in Vietnam, Yale University Press, New Haven.

Luong, Hy V. 2010, ‘Quà và vốn xã hội ở hai cộng đồng nông thôn Việt Nam' ['Gifts and Social Capital in Two Vietnamese Rural Communities'], in H. Luong et al. (eds), Hiện đại và động thái của truyền thống ở Việt Nam: Những cách tiếp cận nhân học [Modernities and the Dynamics of Tradition in Vietnam: Anthropological Approaches], Nhà xuất bản Đại học quốc gia TP, Hồ Chí Minh, Ho Chi Minh City, pp. 397-424.

Luong, Hy V. 2013, 'Giỗ tổ tiên và động thái kinh tế xã hội' ['Ancestral Death Anniversaries and their Socio-economic Dynamics'], in Tín ngưing thờ cúng tổ tiên trong xã hội đương đại [Ancestral Worship Beliefs in Contemporary Societies], Nhà xuất bản Văn hóa thông tin, Hanoi, pp. 344-361.

Luong, Hy V. and Diệp Đình Hoa 2000, 'Bốn cộng đồng nông thôn và thành thị Việt Nam: cảnh quan kinh tế, xã hội, và văn hóa' ['Four Rural and Urban Communities in Vietnam: Economic, Social, and Cultural Landscapes'], in Hy V. Luong (ed.), Ngôn từ, giới, và nhóm xã hội từ thực tiễn tiếng Việt [Discourse, Gender, and Society in Vietnam], Nhà xuất bản Khoa học xã hội, Hanoi, pp. 39-97. 
Lưu Quang Tuấn 2012, 'Socialist Republic of Vietnam: Updating and Improving the Social Protection Index', Asian Development Bank, Technical Assistance Consultant's Report, Project 44152.

Portes, Alejandro 1998, 'Social Capital: Its Origins and Applications in Modern Sociology', Annual Review of Sociology, vol. 24, pp. 1-24.

Rambo, A. Terry 1973, A Comparison of Peasant Social Systems of Northern and Southern Viet-Nam, Southern Illinois University Center for Vietnamese Studies, Carbondale, Illinois.

Unger, Jonathan 1998, Building Social Capital in Thailand: Fibers, Finance, and Infrastructure, Cambridge University Press, Cambridge.

Walder, Andrew 1986, Communist Neo-Traditionalism: Work and Authority in Chinese Industry, University of California Press, Berkeley.

Yang, Mayfair Mei-hui 1994, Gifts, Favors, and Banquets: The Art of Social Relationships in China, Cornell University Press, Ithaca.

Yang, Mayfair Mei-hui 2002, 'The Resilience of Quanxi and Its New Deployment: A Critique of Some New Guanxi Scholarship', China Quarterly, vol. 170, pp. 459-476. 
This text is taken from Connected and Disconnected in Viet Nam: Remaking Social Relations in a Post-socialist Nation, edited by Philip

Taylor, published 2016 by ANU Press, The Australian National University, Canberra, Australia. 